\title{
The Effect of Students' Personality and Learning Styles on Their Motivation for Using Blended Learning
}

Mohammad Hossein Keshavarz ${ }^{*}$, Asegul Hulus ${ }^{2}$

${ }^{1}$ English Language Teaching Department, Girne American University, Kyrenia, North Cyprus

${ }^{2}$ University of Greenwich, Southwood Campus, Mary Seacole Building London SE9 2UG United Kingdom

Corresponding Author: Mohammad Hossein Keshavarz, E-mail: keshavarz22@gmail.com

\section{ARTICLE INFO}

Article history

Received: September 19, 2019

Accepted: November 26, 2019

Published: December 31, 2019

Volume: 10 Issue: 6

Advance access: December, 2019

Conflicts of interest: None

Funding: None

\section{Key words:}

Blended-learning,

Motivation,

Learning Styles,

Learner Personality,

Students' Needs

\begin{abstract}
Blended learning is a revolutionary concept that embraces traditional classroom teaching and online/offline learning. Many studies have been conducted on blended learning; however, research on its effect on motivation with reference to personality and learning styles is scarce. Therefore, the present study set out to fill this niche. To this end, 33 university students from a private university in Northern Cyprus were randomly selected to participate in this study by filling out a questionnaire on the use of blended learning. The questionnaire was analyzed and frequencies of participants' responses were calculated. To supplement the survey with qualitative data, an interview was conducted with ten of the participants on a voluntary basis. The results of both sets of data suggest that students' personality and learning styles play a significant role in increasing their motivation for using blended-learning. Thus, based on these findings, it is suggested that in order to increase learners' motivation, teaching materials and methods should be tailored according to their needs. The findings of the study are interpreted to have direct implications for syllabus designers and teachers.
\end{abstract}

\section{INTRODUCTION}

Today different countries attempt to take advantage of modern technology and innovative methods of teaching such as blended learning to develop their educational systems in order to keep stride with current technological developments and to achieve satisfactory educational outcomes. To achieve such goals, it is essential to make effective use of the existing technology in developing curriculum, streamlining educational processes, and providing a better learning environment for students and teachers alike.

Blended-learning is an extension of a Virtual Learning Environment (VLE), which is an online classroom that allows teachers and students to converse with each other, and to provide class information, and learning supplies via the Web (Techterms.com, 2018). As an innovative teaching method, blended-learning may create an ideal situation for increasing student engagement and achievement in university courses. Although some researchers have casted doubt on the effectiveness of blended-learning, as compared with traditional classroom teaching (e.g., Gagne \& Shepherd, 2001; Woodill \& Officer, 2004), there has been a growing interest in the use of blended learning in different parts of the globe. As research explores the needs of students' in blended-learning environments, the enthusiasm for blended-learning continues to expand rapidly. Over the last couple of decades, there has been a sharp increase in the number of studies on the topic of blended-learning in the fields of intelligence, interactional technologies, and in higher education as online learning provides teachers with a more active approach toward teaching by allowing students to keep up with assignments at home where they may access online additional information on the subject (e.g., Bleed, 2001; Garrison \& Vaughan, 2008; Grandzol, 2004; Lalima \& Lata Dangwal, 2017; Ponzurick, France, \& Logar, 2000; Purnawarman, Susilawati, \& Sundayana, 2016; Trasler, 2002; Vaughan, 2010). A major advantage of blended learning is that it offers students learning support and online collaborations with their teachers and peers as well as 24-hour online access so they can comfortably finish their learning tasks at their own pace any time (Boyd, 2010).

Blended-learning has been successful when put to practice in some educational institutions. For instance, the University of Central Florida (UCF) has adopted blended-learning as a vital plan for over ten years and has found an $85 \%$ achievement rate in the University's blended-learning courses (Innovative Practices Research Project, 2011). Similarly, an investiga- 
tion by the US Department of Education demonstrated better learning results in K-12 classes with instruction entirely on the web or in blended-learning lessons, compared to traditional classes with the guidance of teachers during the learning process (U.S. Department of Education, Office of Planning, Evaluation, and Policy Development, 2010).

Studies on blended-learning have put emphasis on the effectiveness of this innovative method of teaching (e.g., Bleed, 2001; Grandzol, 2004; Trasler, 2002; Vaughan, 2010; Vamosi, Pierce \& Slotkin, 2004). Bleed (2001) asserts that blending-learning provides teachers with the opportunity to upgrade the design of courses, and students' self-coordinated learning improves their adaptability skills. Garrison and Vaughan (2008) reverberate Bleed's claim by arguing that blended learning is the natural combination of mindfully chosen and integrated online technology and innovation. Trasler (2002) also contends that adaptability and versatility, which are features of blended-learning, are crucial factors in motivating, engaging and captivating students' interests. It is obvious that the continued online advancements in technology applied in the learning and training processes have enhanced blending-learning, and new electronic applications have opened doors for students to connect with their classmates, instructors, and make use of extra materials. However, it should not be assumed that all students benefit equally from blended-learning. We should be cognizant of the fact that other parameters such as motivation, personality, and learning styles may affect blended learning. These variables are the main concern of the current study, as will be discussed below.

\section{The Effect of Blended-learning on Motivation}

Motivation is as an intrinsic drive that activates behavior and gives it a path to follow (Romando, 2007). In the discussion of blended-learning and motivation, one must consider external and internal factors. One of the fundamental distinctions between these two types of motivation is that while external motivation is driven by powers that are external to an individual, internal motivation is driven by powers that are internal to that individual (Cerasoli, Nicklin, \& Ford, 2014; Dörnyei, \& Csizér, 1998; Giancola, 2014; Givvin, Stipek, Salmon, \& MacGyvers, 2001). External motivation fundamentally deals with variables that are objective driven, such as the motivation for winning prizes in a contest or finishing a specific assignment satisfactorily (Lin, 2007). On the other hand, internal motivation alludes to significant joy and fulfilment that a person gets when performing a task (Lin, 2007), such as using online sources by students to enhance and facilitate learning, which is the focus of the present study. As a rule, internal and external motivations affect expectations concerning the exercises and practices undertaken during the lesson (Lin, 2007). Similarly, Zimmerman (2000) defines motivation in academic settings as the effort that one makes to fulfil certain objectives, such as passing a course.

Technological innovations in general, and the Internet, in particular, play an increasingly important role in motivating students. As an example, English undergraduates can download English songs and movies, allowing them access to genuine English at a globalized level, which is likely to increase their motivation (Nurul-Islam, 2011). Students can also use the Internet to navigate, to get access to library materials, to complete online tests, to download digital recordings, and so forth (Khanchali \& Ziadat, 2011).

On the positive effects of blended-learning on motivation, it has been found that blended-learning can enhance learning outcome, which in turn my result in increased motivation (Drysdale, Graham, Spring, \& Halverson, 2013; López-Pérez, Pérez-López, \& Rodríguez-Ariza, 2011; Mersal \& Mersal, 2014). Similarly, Drysdale et al. (2013) reviewed 205 doctoral papers in the area of blended-learning and found that a high percentage of doctoral papers revealed an enhancement in student examination results when taught in blended-learning environments.

\section{Learning Styles and its Effect on Motivation}

Every person has a unique learning style. In other words, individuals are different in the way they think and learn, conceptualize, process and retain information, and the manner in which they behave (Hickson \& Baltimore, 1996). In the classroom situation, every student has a unique identity and motivational features that affect the manner in which $\mathrm{s} / \mathrm{he}$ learns and reacts to education. Thus, understanding the way in which students learn is crucially important for teachers and educators (Collinson, 2000; Reid, 1995).

Gardner (2008) proposes seven major learning styles labelled as Visual (spatial), Aural (auditory-musical), Verbal (linguistic), Physical (kinaesthetic), Logical (mathematical), Social (interpersonal) and Solitary (intrapersonal) (Gardner, 2008; Learning-styles-online.com, 2018).

Visual learners prefer to use visuals such as pictures, images, colors, mind gaps and spatial understanding in their learning. Aural learners, on the other hand, prefer to learn with sound, rhythms, and music. Learners with a verbal learning style learn more effectively with the use of words, both in speech and writing, while physical learners prefer to use their sense of touch and they learn by doing things. Next, logical learners use logic, reasoning, and systems to learn. They are good at understanding the bigger picture. Social learners, on the other hand, are good at group work and enjoy working with other people. Finally, solitary learners prefer to study and work by themselves. Awareness of students' learning styles enables educators to provide them with appropriate instructional materials and learning environments (Anderson, 2004).

\section{Learner Personalities and its Effect on Motivation}

Nag (2018) defines learner personality as a determinant of the ways a learner controls her/his emotions and feelings during the learning process. There are basically four types of learner personality, as follows.

1. Extrovert learners who enjoy working with others and share ideas with them. They believe there is better output if they work as part of a group.

2. Introvert learners who function better by studying and working on their own to process information or ideas in their minds. 
3. Sensing (sensual) learners who tend to take in information through the five senses and organize it sequentially.

4. Intuitive learners who are interested in theories and possibilities. They enjoy making guesses when learning, and they prefer learning by using their imagination.

Deci, Vallerand, Pelletier, and Ryan (1991) argue that motivational studies should not disregard the role of other variables such as personality types and learning styles. Students' commitment towards education reflects how they see themselves performing while engaged in learning (Engeström, 2010).

Since research on blended learning is in the early stages of development and the use of blended learning environments is expected to increase in schools during the forthcoming years, conducting research on this topic seems legitimate and necessary. Although many studies have been carried out on blended-learning, there remains many unresolved issues related to the effectiveness of blended-learning in higher education taking into consideration the objectives and demands of 21 st century students. As Graham (2006) states, further research is needed for establishing criteria and methods of using blended-learning by teachers. In particular, more research is needed in factors that affect and increase motivation in blended-learning environments, hence another justification for the present study. Accordingly, this research seeks to tackle some of these issues and investigate factors such as motivation, learning style, and learner personalities which are important in stimulating, sustaining, and increasing student participation in blended-learning. More specifically, the present study seeks to answer the following research questions.

a) to what extent does blended-learning environment increase learner motivation?

b) to what extent do learner personality and learning styles affect motivation in blended-learning courses?

\section{METHOD}

This study employed a mixed-method design, using both qualitative and quantitative data, as explained below.

\section{Participants}

Thirty-three students from a private university in North Cyprus participated in this study. They were from different countries, fields of study, and language background. Their age ranged from 19 to 26 , with the exception of one student who was 38 years old.

\section{Instrumentation}

Two instruments were used in this study: a Likert-scale questionnaire and an interview. The questionnaire aimed at eliciting students' perceptions about their learning styles and personality as well as their experience with and attitudes towards blended learning with reference to motivation. The main items of the questionnaire were taken from Gardner (2008) and Nag (2018); however, some modifications were made according to the aim of the present study. The questionnaire consisted of three sections: personality, learning styles, and motivation. Four items were allocated to the personality section, seven to learning styles, and 20 items to the motivation section, which is the main variable in this study.

To support the results of the quantitative data, an interview was conducted with ten students on a voluntary basis. The interview aimed at investigating the participants' perceptions about the weaknesses and strengths of traditional classrooms versus blended-learning.

\section{Data Collection and Analysis Procedures}

Initially, students from different departments were approached and asked if they had taken blended-learning courses and were willing to take part in the study, in which case they were asked to fill out the questionnaire. Upon completion of the questionnaire, 10 of the 33 participants volunteered to participate in the interview. The interview consisted of 6 questions about the weaknesses and strengths of traditional classroom teaching versus blended-learning. The interviewees were also asked to elaborate on their responses to the questionnaire items in order to gain further insight into their reflections about their learning style, learning personality, and motivation.

The questionnaire was analyzed, using SPSS, to obtain the percentages and frequencies of responses to each item in the questionnaire, while the interviews were qualitatively analyzed focusing on participants' reflections regarding learner personality, learning styles, and motivation as related to blended learning. The results of data analyses are presented below.

\section{RESULTS AND DISCUSSION}

\section{Results and Discussion of the Questionnaire}

As mentioned before, a questionnaire consisting of four sections was given to the participants. Section A was concerned with demographic information, which was summarized above. The results of Sections B, C, and D are presented below.

Section B comprised four main personality types and four mixed ones, as illustrated in Table 1 .

As Table 1 shows, there are four main types of learner personalities: extrovert, introvert, sensing, intuitive, and

Table 1. Frequency and percentage of participants' personality types

\begin{tabular}{lcc}
\hline \multicolumn{3}{c}{ Learner personalities } \\
\hline Personality type & $\mathbf{N}$ & $\mathbf{\%}$ \\
\hline Extrovert & 9 & 25.7 \\
Introvert & 11 & 31.4 \\
Intuitive & 4 & 11.4 \\
Sensing & 6 & 17.1 \\
Extrovert/introvert & 1 & 2.9 \\
Extrovert/intuitive & 2 & 50.7 \\
Extrovert/sensing & 1 & 2.9 \\
Introvert/sensing & 1 & 2.9 \\
Total number of & 35 & 100 \\
personality types & & \\
\hline
\end{tabular}


four mixed learner personalities namely extrovert/introvert, extrovert/sensing, introvert/sensing, and extrovert/intuitive. As can be seen, the majority of the participants labelled themselves either as introvert (31.4\%) or extrovert $(25.7 \%)$. This indicates that while many of the university students in this study prefer to study alone, a good number of them learn through interaction with others in the classroom. The other two main personality types were sensing $(17.1 \%)$ and intuitive (11.4\%). Sensing learners learn sequentially by organizing data the way they prefer, and intuitive learners tend to learn more theoretically. The rest of the participants considered themselves as having a mixed learner personality, which is an interesting and important factor to consider in blended-learning. It must be noted that two of the participants identified themselves with more than one learner personality type, hence 35 learner personalities instead of 33. Figure 1 illustrates the frequency of different learner personality types.

Section C dealt with the participants' learning style. As mentioned before, there are seven major learning styles namely Visual (spatial), Aural (auditory-musical), Verbal (linguistic), Physical (kinaesthetic), Logical (mathematical), Social (interpersonal) and Solitary (intrapersonal). All these learning styles appeared in the descriptive analysis, as illustrated in Table 2.

As shown in Table 2, the total number of learning styles the participants identified themselves with is 92 . As can be seen, two of the most frequent learning styles adopted by the participants were verbal learning style with $21.7 \%$, and social learning style with $17.4 \%$. These two learning styles are related to extrovert personality type since extrovert people often make use of their verbal skills to communicate with others and people with social personality type prefer to work in groups. Other learning styles adopted by the participants include visual learners (18.5), who prefer using visuals such as pictures, images, colors, mind gaps and spatial understanding in their learning, aural learners (15.2\%), who prefer to learn with music, logical learners $(8.7 \%)$, who learn with reasoning and systems, and physical learners (10.9\%), who use their hands and sense of touch in order to learn. Finally, solitary learning style had the lowest percentage $(7.6 \%)$. This is quite strange and unexpected given that solitary learning style is associated with introvert personality type which, as observed in Section B above, enjoyed the highest percentage. Considering that solitary learners prefer to work alone, it seems that certain learning tasks or situations may require students to have mixed learning styles and personality type which do not match each other. In this case, the percentages of these two variables are strikingly different. Therefore, teachers and educators must take students' learning styles and learning personality types into consideration before engaging in blended-learning instruction. As an example, a task that requires group work in a blended-learning platform could be a demotivating factor for solitary and introvert students who prefer to work alone. Figure 2 displays the above percentages.

Section D of the questionnaire dealt with the participants' motivation based on their experience with blended-learning. Participants' responses to the items in the Likert-scale questionnaire are presented below.

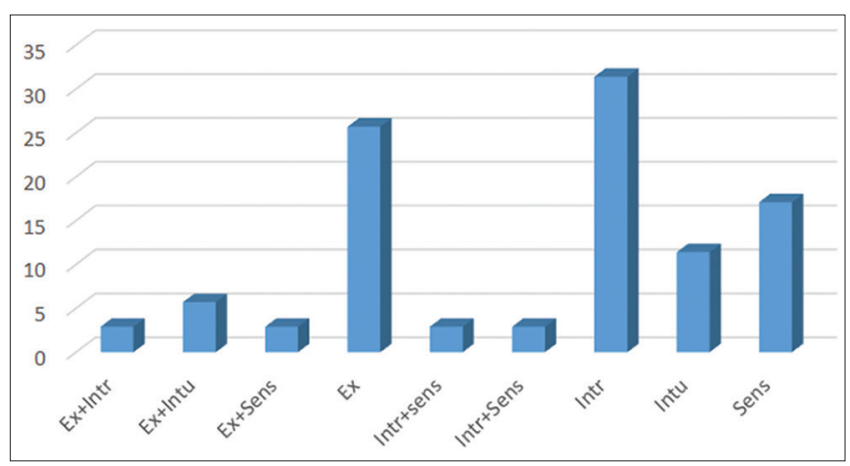

Figure 1. Frequency of the participants' personality types

Key: $\mathrm{Ex}+\mathrm{Intr}=$ Extrovert/Introvert

Ex + Intu $=$ Extrovert/Intuitive

$\mathrm{Ex}+$ Sens $=$ Extrovert/Sensing

$\mathrm{Ex}=$ Extrovert

Intr+Sens= Introvert/Sensing

Intu=Intuitive

Sens $=$ Sensing

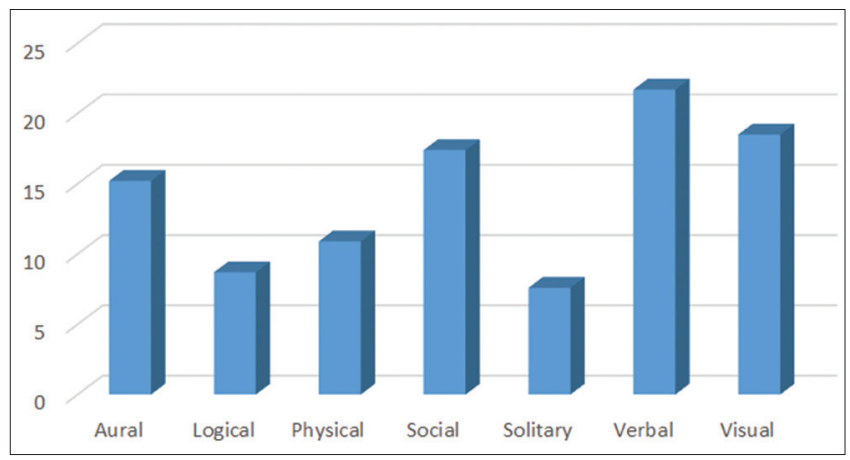

Figure 2. Frequency of the participants' learning styles

Table 2. Frequency of the participants' learning styles

\begin{tabular}{lcc}
\hline & Learning styles & \\
\hline Learning styles & $\mathbf{N}$ & $\mathbf{\%}$ \\
\hline Aural & 14 & 15.2 \\
Logical & 8 & 8.7 \\
Physical & 10 & 10.9 \\
Social & 16 & 17.4 \\
Solitary & 7 & 7.6 \\
Verbal & 20 & 21.7 \\
Visual & 17 & 18.5 \\
Total & 92 & 100 \\
\hline
\end{tabular}

Item 1. The combination of online and face-to-face learning methods would facilitate meaningful learning.

The results of the descriptive analysis show that $30.3 \%$ of the participants strongly agreed and $24.2 \%$ agreed with the above statement. That is, altogether 54.5 participants believed that blended learning does have a meaningful effect on the learning of instructional materials. Of the remaining participants, $21.2 \%$ strongly disagreed, and $9.1 \%$ disagreed with the above statement, while $15.2 \%$ were undecided.

Item 2. Online learning materials can be accessed easily and rapidly, compared to classroom materials. This encourages and motivates learners. 
Analysis of the data demonstrates that $30.3 \%$ of the participants chose the 'neutral' option, while $27.3 \%$ of them disagreed with the statement, and $9.1 \%$ strongly disagreed with it. This indicates that the majority of the students disagreed with this statement or were undecided about it implying that they may be in favour of traditional classroom materials. However, $21.2 \%$ of participants strongly agreed, and $12.1 \%$ agreed that online learning materials are accessed more easily and rapidly. This shows that there are still many students who are in favour of online materials.

Item 3. Getting prompt feedback online from my professor regarding my questions about the course materials, etc. is more encouraging than the traditional classroom setting. The results show that $33.3 \%$ of the participants chose the neutral option. Also $21.2 \%$ of them disagreed with the statement and 9.1\% strongly disagreed with it. This neutrality and disagreement may be due to the lecturers' response rate and the aura of the virtual environment. In contrast, $24.2 \%$ of students agreed and $12.1 \%$ of them strongly agreed with the statement. This indicates that their instructors must have been responsive to them and have tried to take the blended-learning environment seriously and conscientiously.

Item 4. Transition from classroom lectures to materials on the web (e.g., videos and simulations) will result in a good understanding of the instructional materials.

According to the results, $39.4 \%$ of students agreed and $9.1 \%$ strongly agreed with this statement. This high percentage may be attributed to learners who have a verbal and visual learning style since visual learners learn by seeing and verbal learners by speaking, hence a virtual simulation can be considered a perfect learning tool for them. In contrast, $6.1 \%$ of the students strongly disagreed with the statement, and $18.2 \%$ of them disagreed with it while $27.3 \%$ remained neutral. This indicates that learning styles and learning personalities of these three groups of students do not correspond to the statement.

Item 5. A blended-learning session always keeps me alert and focused.

$27.3 \%$ of the participants strongly agreed and $24.2 \%$ of them agreed with this statement presumably because these participants were extrovert learners mixed with other learning styles. However, $27.3 \%$ of the participants remained neutral while $15.2 \%$ disagreed, and $6.1 \%$ of them strong disagreed with the statement. These percentages are probably related to participants' personality types and learning styles namely introvert with solitary and physical learning styles.

Item 6. The use of blended-learning technology in this course encourages me to learn independently.

As the results show, $33.3 \%$ of the participants agreed with this statement, and $15.2 \%$ strongly agreed with it. This was followed by $24.2 \%$ of neutrality, $18.2 \%$ disagreement, and $9.1 \%$ strong disagreement. Thus, the majority of the participants (48.5) tend to support blended-learning as it enables them to be autonomous learners.
Item 7. Thanks to blended-learning, my knowledge has improved compared to similar courses I have taken before. According to the results, the highest percentage in this statement belonged to the neutral option with 54.5 percentage. This was followed by $18.2 \%$ disagreement and $12.1 \%$ strong disagreement. Only $9.1 \%$ of students agreed, and $6.1 \%$ of them strongly agreed with the statement. Therefore, based on these results it can be concluded that blended-learning has not met the expectation of most of the students, compared to traditional classroom courses they had taken before.

Item 8. Thanks to blended-learning, my performance in exams has improved compared to similar courses I have taken before.

The results indicate that $30.3 \%$ of participants agreed with the statement and $12.1 \%$ strongly agreed with it. Therefore, a good percentage of the participants felt that their exam performance has improved as a result of blended-learning. However, $27.3 \%$ of the students remained neutral while $21.2 \%$ disagreed, and $9.1 \%$ of them strongly disagreed with the statement.

Item 9. I make a lot of effort in my blended-learning assignments.

In this item, neutrality enjoys the highest percentage of the results $(39.4 \%)$. This was followed by $30.3 \%$ for agreement, and $9.1 \%$ for strong agreement. The agreement percentages may come from verbal and visual learners along with extroverts. The percentage of disagreement and strongly disagreement was low, 15.2\% and $6.1 \%$, respectively. It should be noted that this statement is directly linked with motivation, as students make a lot of effort in their assignments only when they are genuinely motivated. Therefore, it can be assumed that blended-learning has not been successful with introvert learners, as it has not motivated them enough to engage fully in this kind of learning, nor has it demotivated them enough to give up blende-learning entirely, hence a high percentage of neutrality (39.4\%).

Item 10. Completing blended-learning assignments gives me a satisfying feeling of accomplishment.

The results indicate that $33.3 \%$ of the participants agreed with this statement, and $6.1 \%$ strongly agreed with it. $9.1 \%$ of students strongly disagreed, and $27.3 \%$ disagreed with the statement, while $24.2 \%$ of students remained neutral. Therefore, a good proportion of the participants (39.4\%) completed the tasks to satisfy their needs and feelings of accomplishment.

Item 11. Participation in online group discussion increases my motivation to work.

According to the results, the highest percentage belonged to undecided participants (36.4\%). 15.2\% and $6.1 \%$ of the students disagreed and strongly disagreed with the statement, respectively. Only $33.3 \%$ of the participants agreed, and $9.1 \%$ of them strongly agreed with the above statement. Therefore, it can be assumed that the high percentage of neutrality and disagreement may have been influenced by the responses of introvert learners as they do not like working in groups. 
Item 12. I like the chance to interact with my team members via blogging on course assignments.

The results revealed that $42.4 \%$ of the participants agreed with this statement and $12.1 \%$ of them strongly agreed with it. This indicates that over half of the participants were introvert and solitary learners who are in favour of this aspect of blended-learning, i.e., working via blogs, as they are not communicating with anyone in a public learning environment. However, 24.4 disagreed with the above statement, and 21.2 remained neutral, but no one strongly disagreed with the statement. Therefore, it seems that online interaction via blogging matches most learning styles and personalities.

Item 13. The exchange of views in the discussion forum stimulates my thinking on the subject.

The highest percentage of responses in this item belonged to the agreement scale with $33.3 \%$ followed by $21.2 \%$ strong agreement. This may indicate that online-interaction matches most learning styles and personalities as learners feel at ease communicating with others while being stimulated by online discussions. However, $30.3 \%$ of the participants remained neutral, $12.1 \%$ of them disagreed, and only one participant $(3 \%)$ strongly disagreed with the statement.

Item 14. If I had known this was going to be a blended-learning course, I would not have taken it.

The results show that $33.3 \%$ of the participants disagreed and $9.1 \%$ strongly disagreed with this statement This was followed by $30.3 \%$ neutrality. These percentages indicate that blended-learning creates curiosity in students to try out the course. This type of curiosity usually comes from extroverts, sensing, and intuitive learners, along with the learning styles of social, visual, verbal, logical, and aural. Of the remaining participants, $21.2 \%$ of them agreed with this statement, and only $6.1 \%$ strongly agreed with it. Probably, these learners stayed away from blended-learning courses due to their bad experience with virtual environment.

Item 15. I am willing to take another course using Blended-learning delivery mode.

Based on the results, this statement had a high rate of neutrality $(39.4 \%)$. Thus, students were neither motivated nor demotivated enough to take another blended-learning course. However, $24.2 \%$ of the participants agreed with the statement, and $15.2 \%$ of them strongly agreed with it. Therefore, a good percentage of participants $(39.4 \%)$ were willing to take another blended-learning course, while a small percentage of them were against the idea, with $6.1 \%$ strong disagreement, and $15.2 \%$ disagreement.

Item 16. Additional online materials complicate learning rather than facilitate it.

The results indicate that $36.4 \%$ of the participants agreed that online materials complicate learning and $15.2 \%$ strongly agreed with this statement. The reason for this could be the fact that the extra materials given to the students might not have been helpful and in line with students' learning styles and personalities.
As a result, the majority of the participants found extra materials demotivating. However, $3.0 \%$ of the students disagreed and $27.3 \%$ strongly disagreed with this statement, indicating that the extra material has been tailored to their needs. The rest of the students (18.2\%) remained neutral.

Item 17. The time I spent on blended-learning online would have been more efficient in the classroom.

According to the results, when it comes to judging the effectiveness of blended-learning courses, the majority of the participants were either neutral $(30.3 \%)$ or had negative opinion about such courses $(24.2 \%$ agreed with the above statement, and $15.2 \%$ strongly agreed). This shows that the blended learning course did not match many learning styles and personalities. The remaining participants either disagreed (18.2\%), or strongly disagreed $(12.1 \%)$ with the statement.

Item 18. Collaborative learning experience in the computer-mediated communication environment is better than that in face-to-face learning environment.

The results show that the majority of the participants were neutral (39.4\%) and only $24.3 \%$ of the participants (15.2\% agreed and $9.1 \%$ strongly agreed) believed that collaborative learning experience in the computer-mediated communication environment is more beneficial than the experience in face-to-face learning environment. Therefore, no conclusion can be drawn based on this small percentage. $24.2 \%$ of the participants also disagreed with the above statement, and $12.1 \%$ strongly disagreed.

Item 19. I can easily understand the new online material by reading it on my own.

This statement had a very strong agreement scale with $39.4 \%$ agreement and $12.1 \%$ strong agreement. This can be explained by the fact that according to the questionnaire results many of the participants were introvert learners having solitary learning style who prefer to learn by themselves. Only $3.0 \%$ of the respondents strongly disagreed with the statement and $18.2 \%$ disagreed with it, while $27.3 \%$ of participants remained neutral.

Item 20. I learn better if I listen to a lecture than if I read a textbook on my own.

The highest percentage in this item belonged to the agreement scale with $42.4 \%$ agreement and $18.2 \%$ strong agreement. This shows that the majority of students are in favor of classroom environment. Only $21.2 \%$ of the participants disagreed and $18.2 \%$ remained neutral. It is worth noting that no student leaned towards strong disagreement.

Based on the results of the quantitative data presented above, it can be concluded that educators must have awareness about the learning style and learning personality of students before planning or teaching blended-learning courses since if, for example, a class has a high rate of introverts who prefer to work on their own, a group-related task in a blended-learning platform could be a demotivating factor for them. Along these lines, 
Afip (2014) contends that teaching methods should consider how students see themselves in their learning styles.

Similarly, in statements that were directly linked with motivation and blended-learning, students were mainly neutral or in disagreement with the statement. For example, for the statement "The time I spent online on blended learning would have been more efficient in the classroom", most of the participants were either neutral $(30.3 \%)$ or had negative opinion about such courses (39.4\%). Also in the statement "collaborative learning experience in computer-mediated communication environment is better than that in face-to-face learning environment" the majority of the participants remained neutral $(39.4 \%)$. This shows that blended-learning courses have not matched many learning styles and personalities. These results are in line with Givvin et al.'s (2001) assertion that motivation plays a crucial role in students' education and should be taken into consideration in designing online courses. In other words, blended-learning environment should suit the majority of students' learning personalities and learning styles. As Pianta and Hamre (2009) state, by providing students with suitable, reliable, and safe learning conditions, educators can help them progress independently, become motivated to learn, and be willing to take risks. This, in turn, can help students change their learning styles and learning personalities.

The results of the quantitative analysis also point to individual differences in terms of personality and learning styles. This finding is in line with those of other researchers, such as Ariani, 2013; Carrel, Prince, and Astica, 1996; Collinson, 2000; Hickson and Baltimore, 1996; Iverson, Colky, and Cyboran, 2008. Therefore, such individual differences should be taken into consideration by syllabus designers and teachers.

\section{Results and Discussion of the Interview}

As mentioned before, 10 of the participants volunteered to participate in the interview. The participants consisted of four extroverts, one intuitive learner, three mixed extrovert/ intuitive learners, one introvert learner, and one introvert/ intuitive learner. They were asked six questions about their opinions and perceptions on the weaknesses and strengths of traditional classrooms versus blended-learning as well as further elaboration on their choices in the questionnaire concerning motivation, learning style, and learning personality. The results are presented below.

Q1. Which learner personality in the questionnaire did you relate with most and why?

In answer to this question, three groups of learners (four extroverts, one intuitive learner, and two extrovert/ intuitive learners) stated that they were social learners hence they loved working in groups. However, the two introvert learners and the introvert/intuitive learner said they could not work in groups and wanted to do everything on their own while using their imagination rather than trying to catch up with others. Therefore, it can be concluded that the students' perception and preferences are based on their learning personalities, which hinges on their motivation towards doing the given task. That is, introvert learners seem to be more motivated when they work alone and extrovert learners are better in team work, while intuitive learners are quite flexible in this regard as they can either work as an introvert or extrovert in a given situation. Thus, their motivation which influences their success in an academic setting centers on their ability to adopt more than one learning personality.

Q2. Which learning styles in the questionnaire did you relate with the most and why?

In answer to Question 2, four interviewees who labelled themselves as extroverts chose the learning styles of social, logical, and verbal. One of these extrovert learners also selected the learning style of physical and aural, in addition to the above. Two interviewees who considered themselves as a combination of extrovert and intuitive learners labelled their learning styles as visual, verbal, social, aural, and logical. However, the introvert/ intuitive learner as well as the two introvert learners selected the learning styles of visual, verbal, physical and solitary. The remaining intuitive learner chose the learning styles of logical and visual.

As can be seen, the introvert and extrovert learners, who also have an intuitive learning personality, have similar learning styles. The only difference in their learning styles is that introverts adopt a solitary learning style while extroverts a social one. Therefore, it can be concluded that learner personality affects learning styles, which in turn leads to increased motivation caused by blended-learning. This finding is in line with that of other researchers (Afip, 2014; Ariani, 2013; Carrell, Prince \& Astika, 1996; Collinson, 2000).

Q3. Is the motivation to do a task well based on internal or external factors, such as grades, praise, career prospects, and recognition on the part of your parents or instructors? In this question, three extroverts stated that the motivation to do a task well depends on external factors, such as impressing their parents, and receiving praise from their teachers and friends. However, one of the extroverts stated that he believes the motivation to do well is based on both external and internal factors. Furthermore, two of the interviewees who identified themselves as a combination of extrovert and intuitive learners believed that motivation is based on external factors such as long-term goals and receiving praise for getting good grades.

Similarly, the two introvert learners together with the interviewee with a combination of introvert and intuitive learning style believed that both external and internal factors affect motivation and success. They also maintained that personality affects a person's ability and success. However, the intuitive learner stated that personality influences an individual's choice of external and internal factors of motivation.

Based on the above, it can be concluded that when it comes to the motivation for doing a task well, a stu- 
dent's learning style and personality comes into play in adopting external or internal motivational factors. This finding confirms Lin's (2007) assertion that extrinsic and intrinsic motivation affects an individual's performance.

Q4. In what ways has your motivation to learn changed as a result of blended-learning activities such as online quizzes, online videos, and discussion forums?

This question deals with one of the most important factors explored in this study namely motivation. Of the 10 interviewees, the two introvert learners stated that they hated to be forced into socialization by the blended-learning platform and believed that this platform is not suitable for them. In contrast, the four extroverts stated that they feel comfortable and happy to socialize online and on the blended-learning platform. This, in turn, motivates them to work harder.

Next, the two extrovert/intuitive learners stated that doing quizzes and multi-tasks online gives them motivation to complete the tasks. However, one of these learners stated that his professor gave him too many tasks to be completed in a short period of time. Thus, time pressure and amount of work was an issue for this student as he felt demoralized.

The intuitive learner, on the other hand, stated that blended-learning demotivates him and makes him less active. This is perhaps due to the fact that, according to him, his professor puts everything online and expects the students to do the assignments at their own pace. As a result, this student left everything to the last moment, a fact which normally leads to late submission of assignments. That is why he prefers traditional classroom settings where he is forced to do all the tasks within a limited time period.

The last interviewee who was an introvert/intuitive learner stated that blended-learning motivates him by providing him with authentic and visual materials, in addition to easy access to his instructor online. However, the only matter that demotivates him is the excessive tasks of blended-learning.

These results confirm Boyd's (2010) position that blended-learning offers students learning support and online collaborations with their teacher and peers. Likewise, it offers more adaptabilities as students can finish their tasks at their own pace.

Q5. What is the most important factor in motivating you to engage in blended-learning?

(a) control (i.e., you can choose your tasks, and the time and place for completing them),

(b) challenge (i.e., you enjoy difficult tasks) and, (c) peer support (i.e., you enjoy team work and opportunities to interact with your classmates online).

In answer to this question, all the extrovert learners agreed on peer support since working in a social group is what motivates them most. The two introvert learners stated that control is the factor that could motivate them into engaging in blended-learning as they can control the amount of time they spend on doing their homework. On the other hand, the two extrovert/intuitive learners had two different responses. One of them stated that peer support motivates him into engaging in blended-learning, while the other one said that challenge is the source of motivation for being engaged in blended-learning. Similar to this interviewee, the intuitive learner stated that the challenge associated with blended-learning motivates him most as this factor encourages him to work harder. The last interviewee, who was an introvert/ intuitive learner, answered this question by choosing control as the source of motivation for blended-learning. These results indicate that each student has a unique characteristic and personality hence motivational factors affect them differently. In other words, the interviewees chose different motivating factors based on their learning styles and personalities. This finding is in line with Hickson and Baltimore's (1996) assertion that individuals are different in the way they think, learn, process, and retain information in their brain.

Q6. Based on your experience of taking both blended-learning and traditional lessons, do you prefer blended-learning or traditional lessons? Please elaborate on your answer.

Finally, in answer to the last interview question, the two introvert learners stated that they did not like going to school, and preferred learning alone. Two of the four extroverts said they were in favor of blended-learning over the traditional classroom since they could study wherever they wished and at any time they wanted. They also enjoyed peer support. In addition, the two extroverts mixed with intuitive learning style agreed that the motivation to learn was mostly based on external factors. They also stated that blended-learning motivates them because of peer support and the challenges involved. Furthermore, two of the extrovert learners stated that they preferred a blended-course with an instructor who can make it interesting with a range of appealing tasks. However, the intuitive learner said that he opts for traditional lessons as he prefers to receive all the information from his instructor rather than from online sources. The remaining interviewee, who was an introvert/intuitive learner, stated that he prefers the traditional classroom even though blended-learning has some advantages, such as providing visuals, extra materials, and saving classroom time. He put emphasis on the role of an instructor who can balance in harmony the tasks and information given on the blended-learning platform. Therefore, based on these results, an instructor must take learners' personality and learning styles into consideration when designing or teaching a blende-learning course as these factors come into play in motivating students to engage in a blended-learning learning environment.

In summary, the interview results showed that the extroverts and intuitive learners preferred blended-learning over traditional methods. This is perhaps due to the fact that extroverts enjoy working in a social environment and intuitive learners take more interest in theories and possibilities. 
In other words, since intuitive learners learn more effectively through using their imagination, blended-learning can be more appealing to them as it allows for autonomy and creativity. It is interesting to note that intuitive learners are quite flexible as they can either work as introverts or extroverts in a given situation, hence their motivational factors which lead to their academic success hinges on their ability to adopt more than one learning personality. On the other hand, the introvert learners preferred traditional learning over blended learning perhaps because of teacher's presence in the classroom environment, who may encourage and motivate them more. However, they do not deny the fact that blended-learning is a useful tool regarding learner autonomy and the variety of sources it offers. Some students put emphasis on teachers' role in motivating their students. It is implied form these results that even if students' learning style or personality suits the blended-learning platform, a teacher's negative approach can demotivate them to engage in blended learning.

Moreover, learners with a social learning style were in favor of blended learning as they normally like to work in groups, which is required in blended-learning since collaboration is important in this mode of education. Verbal learners also preferred blended-learning as it requires use of language and recorded speech. In contrast, participants who supported traditional learning were students who had a physical, aural, verbal, and solitary learning style. Solitary learners in particular were in favor of traditional classroom because they mostly prefer to work on their own with the help of their classroom teacher. Blended-learning mostly offers group work, with which solitary learners are not comfortable. Based on the above, it can be concluded that there are individual differences in learning based on different learning styles and learners' personality as a set of characteristics that form an individual's unique character. In addition to cognitive abilities, learners bring their personalities to the classroom. Therefore, as the results of this study indicate, learners' personality affects their motivation towards blended-learning. For example, as was demonstrated above, extrovert learners are more positive towards the use of blended-learning compared to introvert learners. Thus, the assertion made by some scholars (Bonk \& Graham, 2006; Bonk, Kim, \& Zeng, 2005) that blended-learning motivates students is not always true. As illustrated above, not all learning styles and learning personalities match blended-learning. Some students were not motivated by blended-learning since it did not meet their needs based on their learning style and learning personality. This finding confirms Deci et al.'s (1991) position that motivational studies should not disregard the role of other variables such as personality types and learning styles.

\section{CONCLUSION AND PEDAGOGICAL IMPLICATIONS}

Based on the results of this research and students' perceptions of blended-learning with reference to their learning style and personality, it can be concluded that:
1. Students' motivation to learn is affected by their learning style and personality. Thus, if teaching materials and methods are tailored to students' needs, their motivation is likely to increase.

2. The results indicated that certain learner personality types and learning styles do not motivate students to learn in a blended-learning environment. Therefore, teachers should make necessary adjustments to make blended-learning more suitable for different learning styles and personalities.

3. Learner personality affects the educational preferences of students. As the results showed, in contrast to introvert students, extrovert as well as extrovert/intuitive learners were in favour of blended-learning. Therefore, teachers must take precaution not to force introverts mixed with other learning personalities to take part in blended-learning.

4. Learning styles play an essential role in learner motivation. Therefore, teachers must take this into consideration in designing and teaching blended-learning courses. As the results indicated, only visual, verbal, social, and physical learners are motivated to learn through blended-learning, while introvert and solitary learners do not benefit from it.

5. Teachers' strategies can affect learners' motivation as well as learning style with regard to blended-learning. As the results showed, some learners who were in favour of blended-learning turned away from it because their teachers placed a great deal of extra tasks on blended-learning platform. Thus, teachers should be aware of the effect of their strategies on the learning outcome of their students.

\section{LIMITATIONS AND SUGGESTIONS FOR FURTHER RESEARCH}

1. Gender was not a variable in this research; therefore, future studies may consider the role of gender in motivation, learning styles, and learner personality, and their effect on blended-learning.

2. The number of participants in this study was limited to 33 students. Other researchers may conduct a similar study with a larger number of participants.

3. The participants in this study were all adults. Future studies may consider the effect of age on blended-learning by recruiting participants from different age groups.

4. The questionnaire used in this study consisted of multiple-choice items only. In future studies, open-ended questions may also be considered.

\section{REFERENCES}

Afip, L. (2014). Motivating adult learners using blended learning in higher education institutions. Journal of Arts, Science \& Commerce, 5(3), 35-42.

Anderson, T. (2004). Towards a theory of online learning. In T. Anderson, \& F. Elloumi (Eds.), Theory and practice of online learning (pp. 33-60). Edmonton, Canada: Athabasca University Press. 
Ariani, D.W. (2013). Personality and learning motivation. European Journal of Business and Management, 5(10), 26-38.

Bleed, R. (2001). A hybrid campus for the new millennium. Educause Review, 36(1), 16-22.

Bonk, C. J., Kim, K. J., \& Zeng, T. (2005). Future directions of blended learning in higher education and workplace learning settings. In EdMedia + Innovate Learning (pp. 3644-3649). Association for the Advancement of Computing in Education (AACE). Montreal, Canada.

Bonk, C.J., \& Graham, C.R. (2006). The handbook of blended learning environments: Global perspectives, local designs. San Francisco, California: Jossey, Bass/Pfeiffer.

Boyd, D. (2010). Social network sites as networked publics: Affordances, dynamics, and implications. In Zizi Papacharissi (Ed.), a networked self (pp.47-66). London: Routledge.

Carrell, P., Prince, M., \& Astika, G. (1996). Personality types and language learning in an EFL context. Language Learning, 46(1), 75-99. doi: 10.1111/j.1467-1770.1996. tb00641.x

Cerasoli, C., Nicklin, J., \& Ford, M. (2014). Intrinsic motivation and extrinsic incentives jointly predict performance: A 40-year meta-analysis. Psychological Bulletin, 140(4), 980-1008. doi: 10.1037/a0035661

Collinson, E. (2000). A survey of elementary students' learning style preferences and academic success. Contemporary Education, 71(4), 42-48.

Deci, E., Vallerand, R., Pelletier, L., \& Ryan, R. (1991). Motivation and education: The self-determination perspective. Educational Psychologist, 26(3-4), 325-346. doi: 10.1080/00461520.1991.9653137

Drysdale, J., Graham, C., Spring, K., \& Halverson, L. (2013). An analysis of research trends in dissertations and theses studying blended learning. The Internet and Higher Education, 17, 90-100. doi: 10.1016/j.iheduc.2012.11.003

Dörnyei, Z., \& Csizér, K. (1998). Ten commandments for motivating language learners: results of an empirical study. Language Teaching Research, 2(3), 203-229. doi: 10.1177/136216889800200303

Engeström, Y. (2010). Activity theory and learning at work. [online] University of Helsinki. Available at: http://www.helsinki.fi/cradle/documents/Engestrom\%20Publ/Chapter\%20 for\%20Malloch\%20book.pdf [Accessed 2 Feb. 2017].

Gagne, M., \& Shepherd, M. (2001). Distance learning in accounting: A comparison between a distance and a traditional graduate accounting class. Technological Horizons in Education, 28(9), 58-60.

Gardner, H. E. (2008). Multiple intelligences. New York: Basic Books.

Garrison, D. \& Vaughan, N. (2008). Blended learning in higher education. San Francisco, Calif.: Jossey-Bass.

Giancola, F. (2014). Should HR professionals devote more time to intrinsic rewards?. Compensation \& Benefits Review, 46(1), 25-31. doi: $10.1177 / 0886368714537446$

Givvin, K. B., Stipek, D. J., Salmon, J. M., \& MacGyvers, V. L. (2001). In the eyes of the beholder: Students' and teachers' judgments of students' motivation. Teaching and Teacher Education, 17(3), 321-331.

Graham, C. R. (2006). Blended learning environments. In Encyclopaedia of distance learning (pp. 172-179). IGI Global.

Grandzol, J. (2004). Teaching MBA statistics online: A pedagogically sound process approach. Journal of Education for Business, 79(4), 237-244.

doi: 10.3200/joeb.79.4.237-244

Hickson, J. \& Baltimore, M. (1996). Gender-related learning style patterns of middle school pupils. School Psychology International, 17(1), 59-70.

Iverson, K., Colky, D., \& Cyboran, V. (2008). E-learning takes the lead: An empirical investigation of learner differences in online and classroom delivery. Performance Improvement Quarterly, 18(4), 5-18.

doi: 10.1111/j.1937-8327.2005.tb00347.x

Khanchali, M. \& Zidat, A. (2011). The Impact of the internet on the development of students' writing. Revue des Sciences Humaines, 21, 51-63.

Lalima, D. \& Lata Dangwal, K. (2017). Blended Learning: An innovative approach. Universal Journal of Educational Research, 5(1), 129-136. doi: 10.13189/ ujer.2017.050116

Lin, H. (2007). Effects of extrinsic and intrinsic motivation on employee knowledge sharing intentions. Journal of Information Science, 33(2), 135-149. doi: $10.1177 / 0165551506068174$

López-Pérez, M., Pérez-López, M., \& Rodríguez-Ariza, L. (2011). Blended learning in higher education: Students' perceptions and their relation to outcomes. Computers \& Education, 56(3), 818-826.

doi: 10.1016/j.compedu.2010.10.023

Mersal F. A, \& Mersal N. A (2014). Effects of blended learning on new nursing students' outcomes regarding new trends in nursing subject at Ain Shams University. American Journal of Educational Research, 2(11), 1036-1043. doi: 10.12691/education-2-11-6

Nag, A. (2018). Personality types of learners and their effect on learning. Available at: https://blog.commlabindia. com/elearning-design/personality-types-learners [Accessed 23 Aug. 2018].

Nurul Islam, M. (2011). Independent English learning through the Internet. Journal of Language Teaching and Research, 2(5) 1080. doi: 10.4304/jltr.2.5.1080-1085

Overview of learning styles (2017). Retrieved from https:// learning-styles-online.com/overview/

Pianta, R., \& Hamre, B. (2009). Conceptualization, measurement, and improvement of classroom processes: Standardized observation can leverage capacity. Educational Researcher, 38(2), 109-119. doi: 10.3102/0013189x09332374

Ponzurick, T., France, K., \& Logar, C. (2000). Delivering graduate marketing education: An analysis of face-to-face versus distance education. Journal of Marketing Education, 22(3), 180-187. doi: 10.1177/0273475300223002

Purnawarman, P., Susilawati, S., \& Sundayana, W. (2016). The use of Edmodo in teaching writing in a blend- 
ed-learning setting. Indonesian Journal of Applied Linguistics, 5(2), 242-252. doi: 10.17509/ijal.v5i2.1348

Reid, J. M. (1995). Learning styles in the ESL/EFL classroom. Heinle \& Heinle Publishers, International Thomson Publishing Book Distribution Center, 7625 Empire Drive, Florence, KY 41042.

Romando, R. (2007). Motivation theory. Retrieved March 22, 2018, from http://ezinearticles.com/?Motivation-Theory\&id $=410700$.

Techterms.com. (2018). VLE (virtual learning environment) definition. [online] Available at: https://techterms.com/ definition/vle [Accessed 22 Aug. 2018].

Trasler, J. (2002). Effective learning depends on the blend. Industrial and Commercial Training, 34(5), 191195. doi: 10.1108/00197850210437111

U.S. Department of Education, Office of Planning, Evaluation, and Policy Development, evaluation of evidence-based practices in online learning: A me- ta-analysis and review of online learning studies, Washington, D.C., 2010

Vamosi, A., Pierce, B., \& Slotkin, M. (2004). Distance learning in an accounting principles course-student satisfaction and perceptions of efficacy. Journal of Education for Business, 79(6), 360-366. doi: 10.3200/ joeb.79.6.360-366

Vaughan, N. (2010). A blended community of inquiry approach: Linking student engagement and course redesign. The Internet and Higher Education, 13(1-2), 6065. doi: 10.1016/j.iheduc.2009.10.007

Woodill, G. \& Officer, D. C. L. (2004). Where is the learning in E-learning?. A critical analysis of the e-learning industry (Operitel Corporation). Peterborough, Ontario, Canada: Operitel Corporation.

Zimmerman, B. (2000). Self-Efficacy: An essential motive to learn. Contemporary Educational Psychology, $25,82-91$. 